\title{
CORRECTION
}

\section{Correction to: Phase 2 study of NAB-paclitaxel in SensiTivE and refractory relapsed small cell lung cancer (SCLC) (NABSTER TRIAL)}

Francesco Gelsomino, Marcello Tiseo (D), Fausto Barbieri, Ferdinando Riccardi, Luigi Cavanna, Antonio Frassoldati, Angelo Delmonte, Lucia Longo, Claudio Dazzi, Saverio Cinieri, Ida Colantonio, Francesca Sperandi, Giuseppe Lamberti, Stefano Brocchi, Lorenzo Tofani, Luca Boni and Andrea Ardizzoni

British Journal of Cancer (2021) 125:306; https://doi.org/10.1038/s41416-021-01439-1

Correction to: British Journal of Cancer https://doi.org/10.1038/ s41416-020-0845-3, published online 29 April 2020

The original version of this article unfortunately contained a mistake in the affiliation of Dr. Delmonte. The correct affiliation should be: Department of Medical Oncology, Istituto Scientifico Romagnolo per lo Studio e la Cura dei Tumori (IRST) IRCCS, Meldola, Italy. The original article has been corrected. (c) Open Access This article is licensed under a Creative Commons adaptation, distribution and reproduction in any medium or format, as long as you give appropriate credit to the original author(s) and the source, provide a link to the Creative Commons license, and indicate if changes were made. The images or other third party material in this article are included in the article's Creative Commons license, unless indicated otherwise in a credit line to the material. If material is not included in the article's Creative Commons license and your intended use is not permitted by statutory regulation or exceeds the permitted use, you will need to obtain permission directly from the copyright holder. To view a copy of this license, visit http://creativecommons. org/licenses/by/4.0/.

(c) The Author(s) 2021 